\title{
LXII. On the insulated or safety compass lately invented by Mr.Jennings
}

\section{James Horsburgh Esq.}

To cite this article: James Horsburgh Esq. (1819) LXII. On the insulated or safety compass lately invented by Mr.Jennings, Philosophical Magazine Series 1, 53:253, 365-367, DOI: $10.1080 / 14786441908652156$

To link to this article: http://dx.doi.org/10.1080/14786441908652156

里 Published online: 23 Jul 2009.

Submit your article to this journal $₫$

Џ Article views: 2

Q View related articles $₫$ 
Exp. 9.-This fluid being completely freed from muriate of soda, and highly concentrated, was decomposed with subcarbonate of potash. It yielded a copious white precipitate, which, after being thoroughily ignited, gave $1 \cdot 25$ grain of sulphate of magnesia (taking 136.68 of magnesia to be equal to 100 of sulphate of magnesia) to be present in one gallon of the water.

$E x p .10$.- The dilute fluid obtained in process 3, yielded a precipitate by oxalate of ammonia and nitrate of barytes; and being on a further examination found to contain nothing but sulphate of lime, it was decomposed by barytic water; and taking $10 n$ parts of sulphate of barytes to be produced by 71 of sulphate of lime, gave three grains of sulphate of lime to one gallon of water.

The composition of the Thetford chalybeate water is therefore as follows:

Contents in one Gallon.

\begin{tabular}{|c|c|c|c|c|}
\hline Carbonate of iron & . & . & . & ains. \\
\hline Muriate of magnesia & & $\ldots$ & $\ldots$ & $3 \cdot 25$ \\
\hline Muriate of lime & & $\ldots$ & $\ldots$ & $2 \cdot 25$ \\
\hline Sulphate of magnesi & & .. & .. & $1 \cdot 25$ \\
\hline Muriate of soda & .. & .. & .. & $2 \cdot 125$ \\
\hline Sulphate of lime & -. & .. & .. & 3 \\
\hline & & & & $14 \cdot 625$ \\
\hline Carbonic acid gas & .. & . & $12 \cdot 07$ & cubic inches. \\
\hline Oxygen gas & $\cdots$ & .. & $1 \cdot 21$ & \\
\hline Atmospheric air & $\cdots$ & 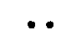 & $3 \cdot 04$ & \\
\hline & & & $\overline{16 \cdot 32}$ & \\
\hline
\end{tabular}

LXII. On the Insulated or Safety Compass lately invented by Mr.Jennings. By James HorsBuRGH, Esq. Hydrographer to the Honourable the East India Company.

$$
\text { To Mr. Tilloch. }
$$

Dear sir, - As the pages of the Philosophical Magazine are always open to give publicity to the labours of those who are gifted with superior talents, I trust you will be able to afford room for a few observations on the insulated or safety compass, lately invented by Mr. Jennings, which is not yet sufficiently known, although it will probably add greatly to the security of uavigation and commerce, when brought into general use.

Several men of science have been convinced, by attending to experiments made by Mr. Jennings, and his liberal explanation, that he has discovered a method of arresting the progress of the magnetic fluid, and securing the magnetic needle from being disturbed 
disturbed by the contiguity of small pieces of iron, such as have been liable to disturb the mariner's cumpass hitherto, and have often led to the loss of much property and many valuable lives. This discovery seems capable of further extension; for the needle can be protected from the influence of large masses of iron, or even from the local attraction of all the iron in a ship:-but this cannot be effected without considerable expense, and it would not be of general utility; whereas the protection of the needle from the influence of small pieces of iron must be always useful, and afford great comfort to those intrusted with lives and property when navigating in narrow seas or dangerous situations.

Capt. Dunbar, an experienced seaman, who was many years a master in the royal navy, and now commander of the Brassa, lately arrived from Smyrna, had one of the insulated compasses in that vessel during the voyage, of which he writes in the highest terms in a letter to Mr. Jennings, stating that it was not attracted by iron, although part of the frame, beams, bitts, cables, and cargo of the Brassa, consisted of iron. During his stay at Malta, Admiral Penrose sent for the compass, and tried it against a large magnet which would lift forty-two pounds of iron by its attractive power, but it did not influence the compass materially. This circumstance induced the Admiral to say, he deemed it the most important invention that he had ever seen.

His Majesty's ship Isabella had one of the insulated compasses on board during the late exploration of Baffin's Bay, which obviated the effects of the local attraction of iron, although the needle of that compass was not so perfect as those at present constructed by $\mathrm{Mr}$. Jennings, the result of experience and attentive observation. 'The ships which have lately sailed again for Baffin's Bay have been supplied by him with a great number of magnetic needles on a new and peculiar construction, from which it will probably be proved, that the needles which unite the figure of the horizontal and dipping needle, are those most proper for the purposes of navigation; and by the others, we may expect to gain more knowledge of the laws which govern the magnetic fluid, because in those regions it appears to act with increased energy, as if flowing from the immediate theatre or focus of magnetism. Several of these iustruments I have seen; and the inventor, in the most candid and unreserved manner, gave me a satisfactory explanation of their principles, $\rightarrow$ which has convinced me of the wonderful fertility and orjginality of Mr. Jemnings's mind; and to several experienced officers of the royal navy, and of the East India Company's service, as well as to myself, his inveutions appear to be highly deserving of public encouragement; and it is to be hoped that the intrinsic value of the insu- 
lated compass will soon bring it into general use, as an indispensable aid to the security of navigation.

\section{Dear sir,}

I am your obliged and faithful servant, Hydrographical Ofice, East India House, J.AMES HORSEURGT. May 15,1819 .

* * We have been informed, but we know not how correctly, that $\mathrm{Mr}$. Jennings effects the insulation of the needle by inclosing it in a double case, having the space between filled with clippings of iron, previously beated, or, as it is called, cemented with red oxide of iron or hematite. If Mr. Jennings himself or Mr. Horsburgh will fumish us with the necessary particulars, we will cheerfully devote a portion of our pages to the making known more generally the nature and merits of so useful a discovery and application.-EDIT.

LXIII. Notices respecting New Books.

Remarks on the Account of the late Voyage of Discovery to Baffin's Bay, published ly Captain J. Ross, R.N. By Captain Edward Sabine, Royal Artillery. 40 pages, 8 vo.

$\mathbf{I}_{\mathrm{v}}$

$\mathbf{N}$ our last we moticed the work referred to in the title of this small publieation, and justice demands that we should also notice the subject of the work before us. The author states the object of his pages to be, "to counteract the erroneous impression which a perusal of 'Captain Ross's recent publication might produce concerning the author's employments, services, and opinions during the voyage." "As Captain Ross's is not an offcial but a private work, I should," says Captrin Saline, " have been unconcerned had the mention of my name or occupation been cven wholly unnoticed; but when I perceive that observations which I was sent to make are therein published as having been made or furnished by others, and various information copied from my papers is given as his own, whilst I am principally introduced as having held an appointment (that of Naturalist) the duties of which I am represented as not having fulfillad, but which duties formed no part of my official engagement; I am obliged in, justice to myself, and in consideration of the respect due to the authority by which I had the honour of being recommended, to show the true nature of my undertaking, and that I have not failed in executing it; to claim the observations and information which -are exclusively my own, and to remark on other points with which Captain Ross has comnected ny name."

The author shows, by a letter from Mr. Brande, writen by the direction of the President and Council of the Royal Society, addressed 